\title{
RANCANG BANGUN APLIKASI ABSENSI GURU DI SMK NEGERI 1 PANYINGKIRAN BERBASIS DESKTOP MENGUNAKAN VISUAL BASIC.NET
}

\author{
Nunu Nurdiana ${ }^{1}$, Yusup Zarkasi ${ }^{2}$ \\ Teknik Informatika, Fakultas Teknik Universitas Majalengka \\ Email: nunu.nrd@gmail.com
}

\begin{abstract}
ABSTRACK
Didalam dunia pendidikan proses absensi merupakan proses yang paling penting. Tidak hanya siswa siswi saja guru pun wajib melakukan absensi menentukan kualitas pekerjaan nya sebagai pengajar di sekolah. Salah satunya adalah dengan sistem absensi guru SMKN 1 Panyingkiran masih menggunakan absensi guru secara manual (kertas). Absensi secara manual masih belum ekonomis, efektif dan efisien. Adapun tujuan aplikasi ini untuk mempermudah dalam pendataan absensi guru SMKN 1 Panyingkiran dengan menggunakan pemograman Visual Basic.NET dengan database Microsoft Access dan Scanner Barcode untuk mempermudah dalam proses pengolahan serta pembuatan laporannya.Metode RAD mempunyai 3 tahapan utama seperti berikut ini: Rencana Kebutuhan (Requirment Planing) Pada tahap ini, user dan analyst melakukan semacam pertemuan untuk melakukan identifikasi tujuan dari aplikasi atau sistem dan melakukan identifikasi kebutuhan informasi untuk mencapai tujuan. Proses Design(Design Workshop) Pada tahap ini adalah melakukan proses desain dan melakukan perbaikan-perbaikan apabila masih terdapat ketidaksesuaian desain antara user dan analyst. Implementasi(Implementation)
\end{abstract}

Kata Kunci : Absensi Scanner Barcode, Pendidikan, RAD, UML

\section{PENDAHULUAN}

Peningkatan kualitas sumber daya manusia merupakan prasyarat mutlak untuk mencapai tujuan pembangungan. Salah satunya untuk meningkatkan kualitas sumber daya manusia adalah pendidikan, sehingga kualitas pendidikan harus senantiasa diangkat sebagai faktor penentu keberhasilan, maka kualitas sumber daya manusia diangkat melalui berbagai program pendidikan yang dilaksanakan secara sistematis dan terarah berdasarkan kepentingan yang mengacu pada kemajuan ilmu pengetahuan dan teknologi.

Dengan berkembangnya teknologi dan informasi yang ada, diharapkan dunia pendidikan berjalan sesuai dengan perkembangan yang ada. Didalam dunia pendidikan proses absensi merupakan proses yang paling penting. Tidak hanya siswa siswi saja guru pun wajib melakukan absensi menentukan kualitas pekerjaan nya sebagai pengajar di sekolah.

SMKN 1 Panyingkiran merupakan salah satu Sekolah Menengah Kejuruan yang banyak diminati di daerah Majalengka. Dari hasil redaksi kemarin di SMKN 1 Panyingkiran ialah Sekolah yang bagus harus mempunyai sistem yang bagus juga. Salah satunya adalah dengan sistem absensi guru SMKN 1 Panyingkiran masih menggunakan absensi guru secara manual (kertas). Absensi secara manual masih belum ekonomis, efektif dan efisien. Adapun tujuan aplikasi ini untuk mempermudah dalam pendataan absensi guru SMKN 1 Panyingkiran dengan menggunakan pemograman Visual Basic.NET dengan database Microsoft Access dan Scanner Barcode untuk mempermudah dalam proses pengolahan serta pembuatan laporannya.

Berdasarakan latar belakang di atas, maka masalah yang dapat dirumuskan adalah sebagai berikut :

Bagaimana mengimplementasikan aplikasi data absensi guru dan Bagaimana guru bisa dengan mudah melakukan input daftar hadirnya ?

\subsection{Landasan Teori}

A. Pengertian Sistem

Sistem mengandung arti kumpulan komponen - komponen yang memiliki keterkaitan antara satu dengan yang lain. Sedangkan "Informasi" bisa diartikan sebagai data". Dari kedua definisi tersebut system 
informasi dapat diartikan sebagai "suatu system yang dibuat oleh manusia yang terdiri dari komponen - komponen dalam organisasi untuk mencapai suatu tujuan yaitu menyajikan informasi”. (Ladjamudin, 2013) Ada beragam definisi sistem informasi, dari berbagai definisi tersebut dapat disimpulkan bahwa sistem informasi mencakup sejumlah komponen (manusia, teknologi, informasi, prosedur kerja), sesuatu yang diproses (data menjadi informasi) dan dimaksudkan untuk mencapai suatu sasaran atas tujuan. (Angga Hanggar Satyawan dkk, 2013:61)

\section{B. Pengertian Aplikasi}

Istilah aplikasi berasal dari bahasa inggris "application" yang berarti penerapan, lamaran ataupun penggunaan. Sedangkan secara istilah, pengertian aplikasi adalah suatu program yang siap untuk digunakan yang dibuat untuk melaksanakan suatu fungsi bagi pengguna jasa aplikasi serta penggunaan aplikasi lain yang dapat digunakan oleh suatu sasaran yang akan dituju. Menurut kamus komputer eksekutif, aplikasi mempunyai arti yaitu pemecahan masalah yang menggunakan salah satu tehnik pemrosesan data aplikasi yang biasanya berpacu pada sebuah komputansi yang diinginkan atau diharapkan maupun pemrosesan data yang diharapkan. Aplikasi biasanya berupa perangkat lunak yang berbentuk software yang berisi kesatuan perintah atau program yang dibuat untuk melaksanakan sebuah pekerjaan yang diinginkan. Selain itu aplikasi juga mempunyai fungsi sebagai pelayan kebutuhan beberapa aktivitas yang dilakukan oleh manusia seperti sistem untuk software jual beli,

\section{Pengertian Absensi}

Pengertian absensi atau kartu jam hadir ialah dokumen yang mencatat jam hadir setiap karyawan di perusahaan atau intansi. Catatan jam hadir karyawan tersebut dapat berupa daftar hadir biasa, dapat juga pula berbentuk kartu hadir dan database komputer yang diisi dengan mesin pencatat waktu. Pekerjaan mencatat waktu pada dasarnya dapat dipisahkan menjadi 2(dua) bagian yakni pencatatan waktu hadir (attendance time keeping) dan juga pencatatan waktu kerja (shop time keeping). Pencatatan jam hadir pada hadir pada kartu jam hadir yang dilakukan oleh pada setiap pegawai atau pekerja bisa mempengaruhi gaji bersih atau take home play yang akan diterima oleh si pegawai atau pekerja setiap bulannya. Karena jika pegawai atau pekerja lupa ataupun tidak mencatatkan jam hadirnya akan dapat mempengaruhi komponen-komponen yang ada pada gaji,

\section{Unifed Modeling Languange (UML)}

UML merupakan pengganti dari metode analisis berorientasi objek dan design berorientasi objek $(O O A \& D)$ yang dimunculkan sekitar akhir tahun 80-an dan awal tahun 90-an. UML merupakan gabungan dari metode Booch, Rumbaugh(OMT) dan Jacobson. Tetapi UML ini akan mencakup lebih luas dari pada $O O A \& D$. Pada pertengahan pengembangan UML dilakukan standarisasi proses dengan OMG(Object Management Group) dengan harapan UML akan menjadi bahasa standar pemodelan pada masa yang akan datang.

UML disebut sebagai bahasa pemodelan bukan metode. Kebanyakan metode terdiri paling sedikit prinsip, bahasa pemodelan dan proses. Bahasa pemodelan (sebagian besar grafik) merupakan notasi dari metode yang digunakan untuk mendesain secara cepat.

\section{METODE PENELITIAN}

Metode RAD mempunyai 3 tahapan utama seperti pada gambar berikut ini:

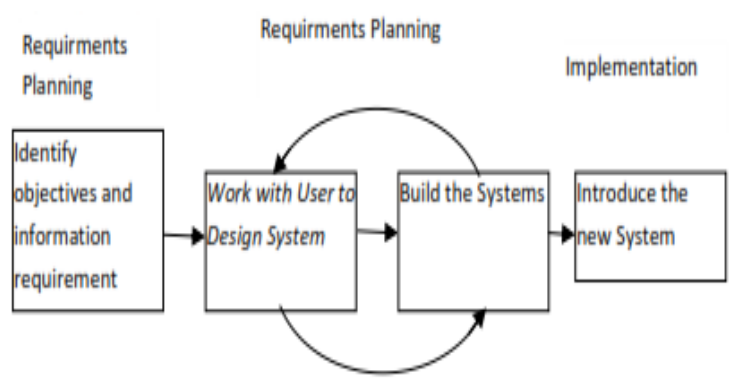

Gambar 2.1 Tahapan-Tahapan Penelitian

1. Rencana Kebutuhan (Requirment Planing)

Pada tahap ini, user dan analyst melakukan semacam pertemuan untuk melakukan identifikasi tujuan dari aplikasi atau sistem dan melakukan identifikasi kebutuhan informasi untuk mencapai tujuan.

2. Proses Design(Design Workshop) Pada tahap ini adalah melakukan proses desain dan melakukan perbaikan- 
perbaikan apabila masih terdapat ketidaksesuaian desain antara user dan analyst.

3. Implementasi(Implementation)

Setelah desain dari sistem yang akan dibuat sudah disetujui baik itu oleh user dan analyst, maka pada tahap ini programmer mengembangkan desain menjadi suatu program. Setelah program selesai baik itu sebagian maupun secara keseluruhan, maka dilakukan proses pengujian terhadap program tersebut apakah terdapat kesalahan atau tidak sebelum diaplikasikan pada suatu organisasi. Pada saat ini maka user bisa memberikan tanggapan akan sistem yang sudah dibuat serta persetujuan mengenai sistem tersebut

\section{HASIL DAN PEMBAHASAN}

\subsection{Sistem Yang Sedang Berjalan}

Sistem yang sedang berjalan saat ini ialah datangnya guru untuk mengajar dan mengabsen pada sebuah kertas yg disediakan oleh pihak sekolah.

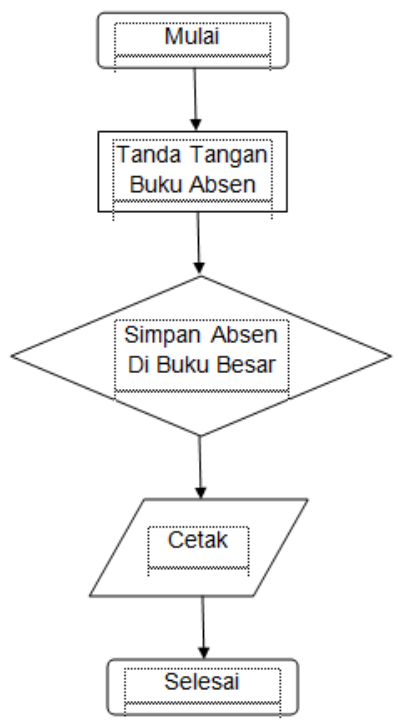

Gambar 3.1 Flowchart system yang berjalan pada data absensi guru

Flowchart diatas menjelaskan alur pembuatan absensi guru, mulai dari tanda tangan buku absensi harian, lalu simpan absen buku besar, atau bisa langsung dicetak pada setiap bulannya.

\subsection{Evaluasi Permasalahan}

Diketahui bahwa sistem yang sedang berjalan dengan keadaan demikian, ada beberapa kelemahan pada sistem tersebut yang harus dibenahi dan dipermudah proses kinerjanya. Sebagai evaluasi permasalahan pembuatan sistem absensi data guru ini, penulis menjabarkan kelemahan-kelemahan sistem sebagai berikut :

1. Pencatatan absensi data guru memerlukan proses yang cukup memakan waktu

2. Untuk melihat absensi data guru harus dilaakukan pencarian pada arsip

3. Pencetakan berulang-ulang karena tidak tersimpan secara praktis

Dari beberapa kelemahan yang mungkin terjadi seperti diatas dengan berbagai konseksuensi pencatatan secara manual, maka penulis membuat suatu usulan terdahap sistem tersebut. Usulan yang penulis lakukan adalah merubah sistem yang sedang berjalan secara manual menjadi sistem yang terkomputasi dengan resiko yang dapat lebih diminimalisir. Disamping itu pembuatan sistem ini diupayakan tidak akan menggangu kinerja pada bagian lain. Karena pembuatan sistem ini memberikan kemudahan kepada pengelola absensi data guru.

\subsection{Analisis Yang Akan Diajukan}

Dari evaluasi permasalahan yang penulis lakukan, maka dalam pembuatan sistem absensi ini yang akan dibuat adalah sistem absensi data guru. Dari setumpuk berkas yang tersimpan yang merubah sistem manual menjadi terkomputasi. Disamping itu, sistem ini akan memberikan kemudahan dalam pencarian absensi data guru dan pelaporan absensi data guru. Adapun sistem yang akan diajukan penulis agar menjadi sistem terkomputasi dapat terlihat pada bagian alur dokumentasi dibawah ini dengan Flowchart usulan : 


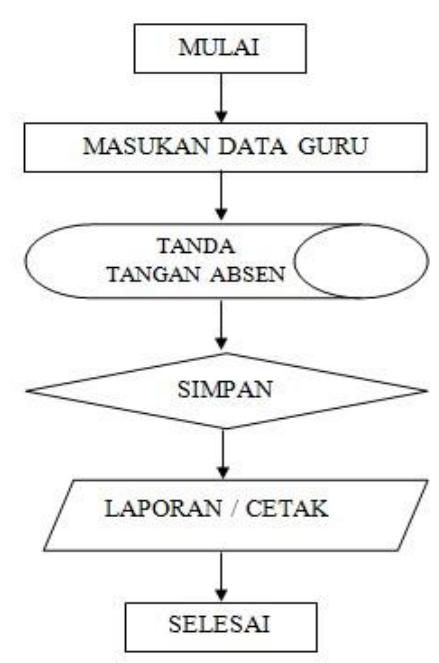

Gambar 3.2 Flowchart yang diajukan pada data absensi guru

\subsection{Hasil Perancangan}

Perancangan sistem aplikasi absensi guru di SMKN 1 Panyingkiran merupakan proses perancangan dari program aplikasi yang akan menghasilkan spesifikasi dari suatu program yang akan dibangun. Dalam perancangan ini penulis menggunakan berapa metode dalam diagram UML yaitu Use Case Diagram, Class Diagram, Sequence Diagram, Activity Diagram, dan Perancangan interface. Adapun perancangan database nya menggunakan ERD (Entitiy Relation Diagram). Didalam terdapat ada 3 objek yaitu :

1. Admin sebagai pemegang server komputer yang mengatasi bila terjadi masalah

2. Karyawan sebagai guru di SMKN 1 Panyingkiran yang mempunyai card barcode tersebut untuk mengabsen dirinya awal datang dan waktu pulang datang

3. Pimpinan sebagai kepala sekolah SMKN 1 Panyingkiran yang mempunyai seluruh kewenangan dengan melihat hasil cetak laporan yang di berikan olah admin kepada kepala sekolah.

\section{A. Use Case Diagram}

Use Case Diagram merupakan pemodelan untuk mengetahui kelakuan (Behavior) dari sistem yang akan dibuat, dan berikut adalah rancangan Use Case Diagram pada Aplikasi absensi guru di SMKN 1 Panyingkiran.

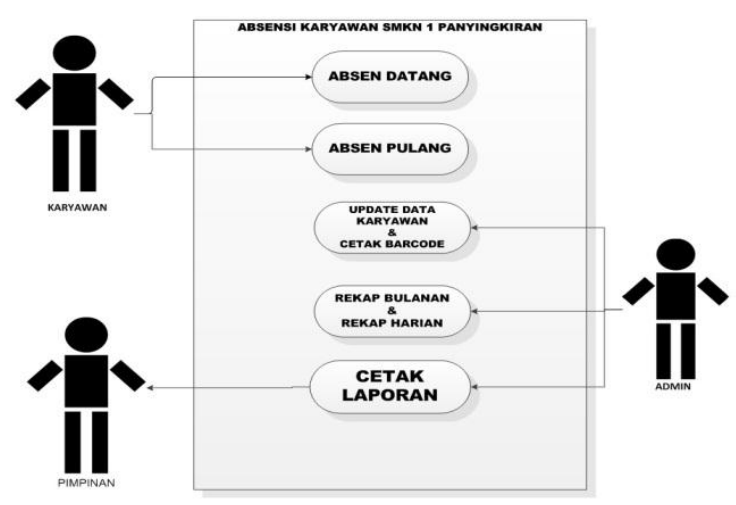

Gambar 3.3 Use Case Diagram

\section{B. Class Diagram}

Class Diagram menggambarkan struktur sistem dari segi pendefinisian kelas - kelas yang akan dibuat untuk membangun sistem, dan berikut adalah rancangan Class Diagram pada Aplikasi absensi guru di SMKN 1 Panyingkiran.

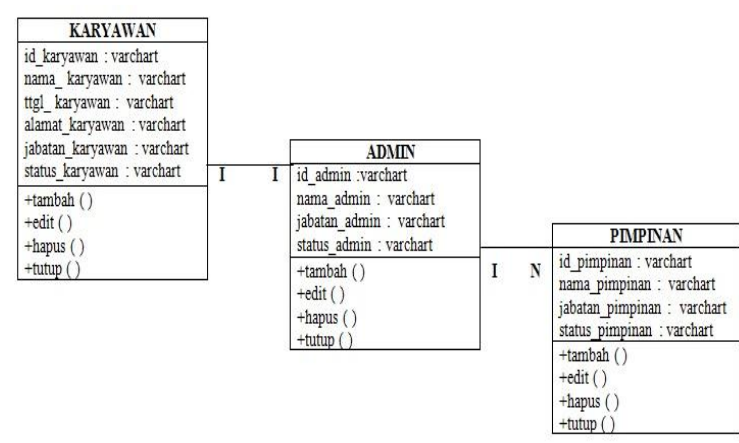

Gambar 3.4 Class Diagram

\section{Sequance Diagram}

Perancangan Sequence Diagram bertujuan untuk menggambarkan kolaborasi dinamis antar sejumlah objek, kegunaannya untuk menunjukkan rangkaian pesan yang dikirim antar objek, dan juga interaksi antar objek. Berikut ini merupakan rancangan Sequence Diagram pada Aplikasi absensi guru di SMKN 1 Panyingkiran. 


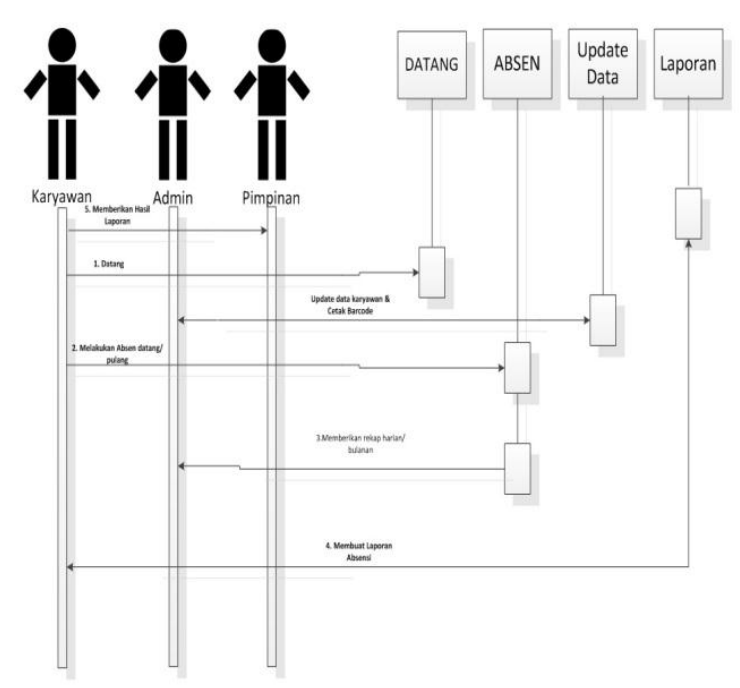

Gambar 3.5 Sequence Diagram

\section{Activity Diagram}

Activity Diagram digunakan untuk memodelkan aspek dinamis dari sistem. Activity Diagram secara esensial mirip dengan alir (Flowchart), memperlihatkan aliran kendali dari suatu aktivitas ke aktivitas lainnya. Dengan Activity Diagram, kita juga memodelkan aliran-aliran dari objek dalam pergerakannya dari suatu state ke state lainnya dalam suatu aliran kendali.

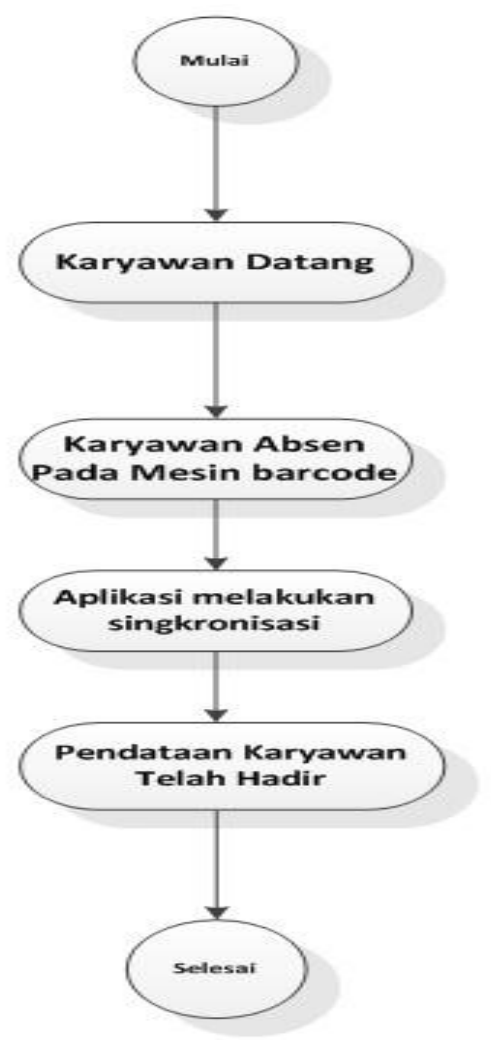

Gambar 3.6 Activity Diagram

\section{E. Perancanagan Interface}

Perancangan Interface bertujuan sebagai gambaran bagaimana pemetaan menu dan submenu yang ada dalam interface yang akan dibuat, jadi tampilan ini hanya di buka khusus admin saja seadainya karyawan ingin membuka aplikasi ini tidak diperbolehkan karena karyawan tidak harus buka aplikasi hanya cukup memasukan card barcode ke mesin scanner lalu aplikasi melakukan singkronisasi menjadi karyawan hadir. Dalam perancangan ini terdiri dari perancangan form menu utama, form buat barcode baru, form data karyawan, form absensi karyawan form rekap laporan dan form keterangan aplikasi.

\section{F. Perancanagan Interface Form Menu utama}

Form ini menjelaskan tentang tampilan awal aplikasi absensi guru di SMKN 1 Panyingkiran di dalamnya ada logo dan ucapan selamat datang.

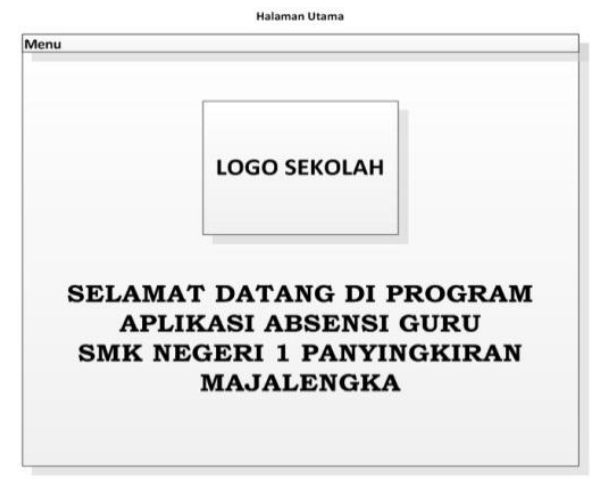

Gambar 3.7 Form Menu utama

\section{G. Perancanagan Interface Form Buat Barcode Baru}

Form ini menjelaskan tentang tampilan pembutan barcode baru yaitu dimana ada karyawan yang belum membuat barcode bisa memasukan data dirinya dan mendapatan kode untuk menyatakan dia hadir. 


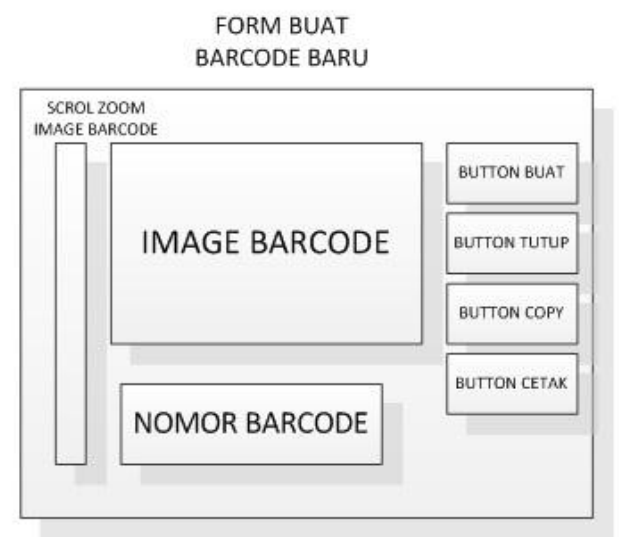

Gambar 3.8 Form Buat Barcode Baru

\section{H. Perancanagan Interface Form Data Karyawan}

Form ini menjelaskan tentang tampilan data karyawan yang telah masuk pada database di dalam aplikasi absensi ini, dan bisa mengetahui semua total karyawan.

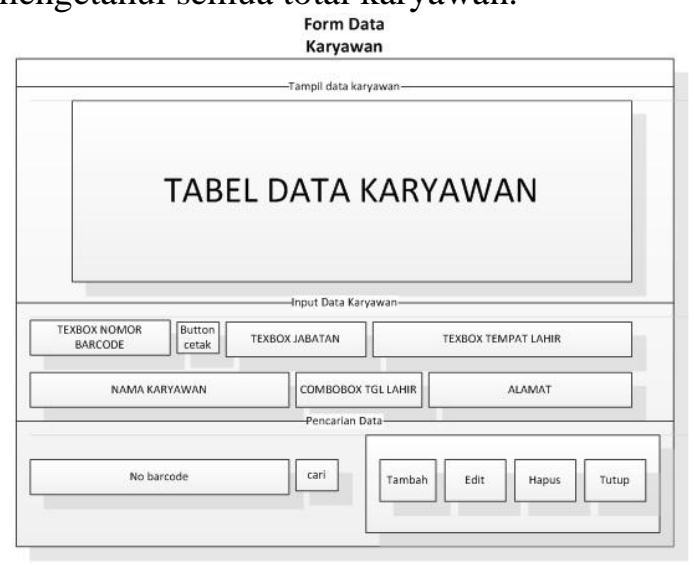

Gambar 3.9 Form Data Karyawan

\section{Perancanagan Interface Form Data}

\section{Absensi Karyawan}

Form ini menjelaskan tentang tampilan mengetahui seluruh jumlah hadir karyawan.

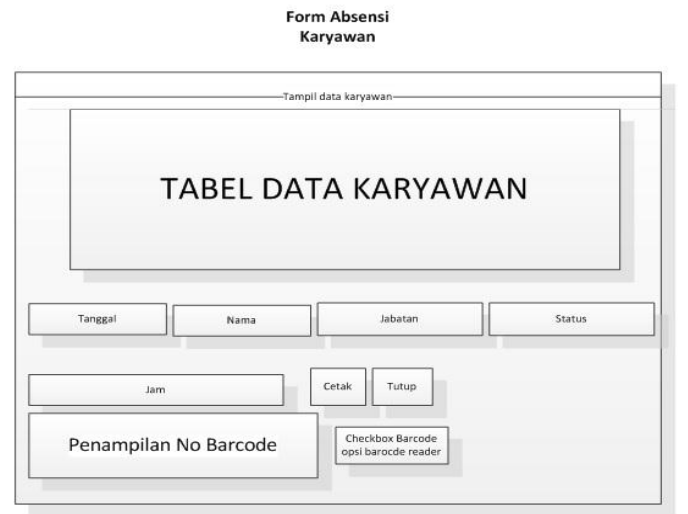

Gambar 3.10 Form Data Absensi Guru / Karyawan

\section{J. Perancanagan Interface Form Rekap Laporan}

Form ini menjelaskan tentang tampilan perekapan daftar hadir untuk waktu ada perhari ada perbulan dari satu karyawan tersebut tujuan nya untuk di ketahui oleh kepala sekolah.
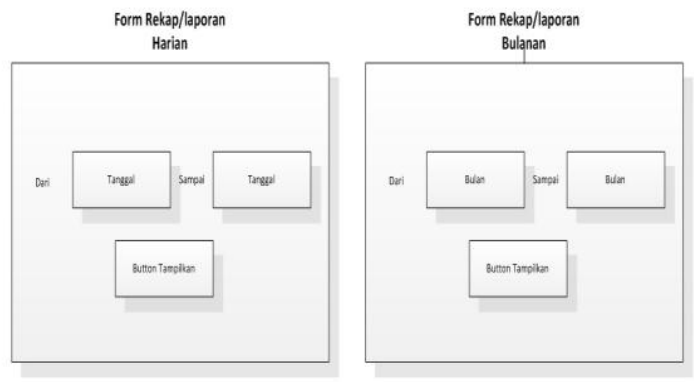

Gambar 3.11 Form Rekap Laporan

\section{K. Perancanagan Interface Form \\ Keterangan Aplikasi}

Form ini menjelaskan tentang tampilan keterangan aplikasi ini yang di dalamnya ada hak cipta pembutan aplikasi absensi guru di SMKN 1 Panyingkiran.

Form About

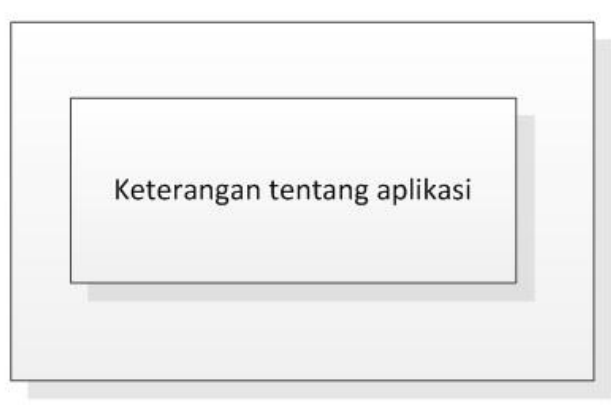

Gambar 3.12 Form Keterangan Aplikasi

\subsection{Hasil Implementasi}

Implementasi dari aplikasi program yang dibuat ini berupa tampilan-tampilan program yang terdiri dari :

\section{A. Form Menu utama}

Form ini menjelaskan tentang tampilan awal aplikasi absensi guru di SMKN 1 Panyingkiran di dalamnya ada logo dan ucapan selamat datang. Yang mengenalkan Aplikasi Absensi ini. 


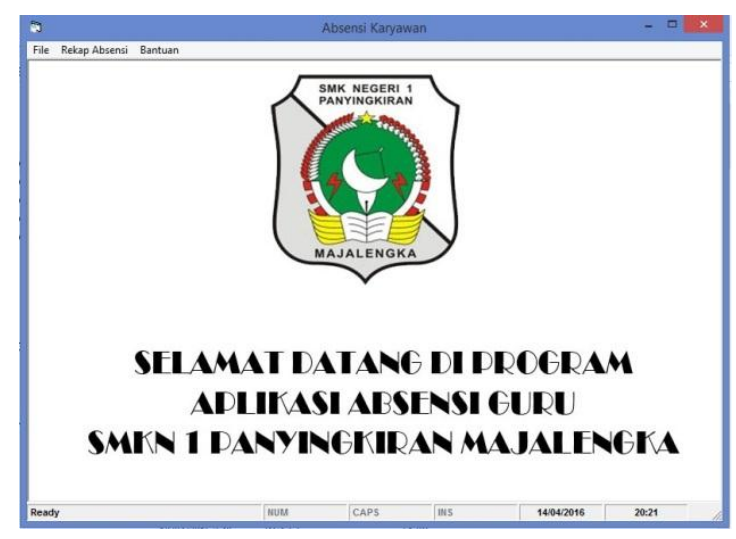

Gambar 3.13 Tampilan Menu utama

\section{B. Form Buat Cetak Barcode}

Form ini menjelaskan tentang tampilan pembutan barcode baru yaitu dimana ada karyawan yang belum membuat barcode bisa memasukan data dirinya dan mendapatan kode untuk menyatakan dia hadir. Dengan cara menggunakan mencetak kode pada kartu masing masing guru / karyawan. Dengan langkah kerjanya masukan kode id guru 12 digit pada angka barcode lalu tekan buat lalu tampil di atas gambar barcode untuk guru tersebut. Apabila ingin langsung di cetak maka tekan tombol cetak, lalu bila ingin di copy barcode nya bisa tekan tekan copy nanti paste nya di open office dan apabila ingin keluar dari menu cetak barcode tekan tutup.

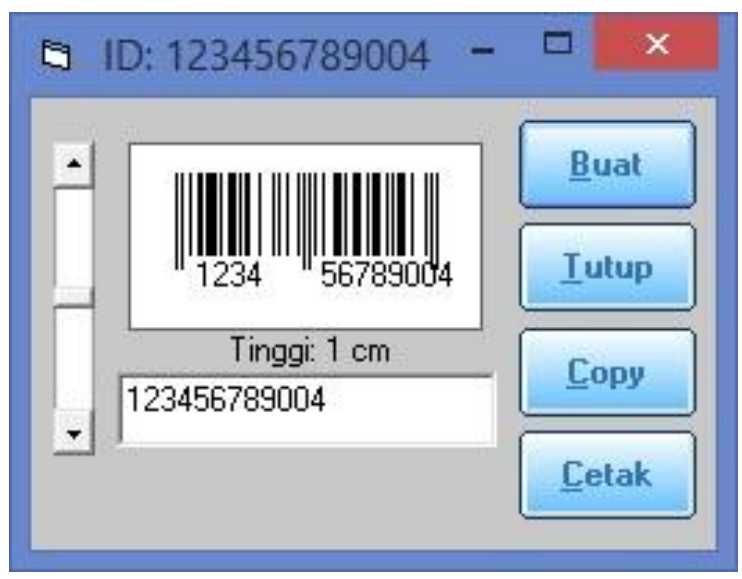

Gambar 3.14 Tampilan Buat Barcode Baru

\section{Form Data Database Guru / Karyawan}

Form ini menjelaskan tentang tampilan data karyawan yang telah masuk pada database di dalam aplikasi absensi ini, dan bisa mengetahui semua total karyawan. Cara untuk memasukan data guru yang buru ialah tekan tambah pertama barcode yang dimasukan kembali ke tadi di buat nomor id lalu enter maka masukan data data yang di bawahnya sampaikan alamat selesai dan tekan tombol simpan. Maka secara otomatis akan tampil diatas dan tersimpan pada databasenya. Untuk mengedit tinggal masukan nomor id dan tinggal merubah apa yg harus dibenarkan datanya. Dan tomobol hapus caranya tekan bagian database mana yg akan di hapus lalu tekan tombol hapus maka data terhapus begitu juga pada databasenya akan terhapus. Dan terakhir tomb........ar maka tinggal tekan tombol tutup saja maka akan keluar dari menu data guru / karyawan.

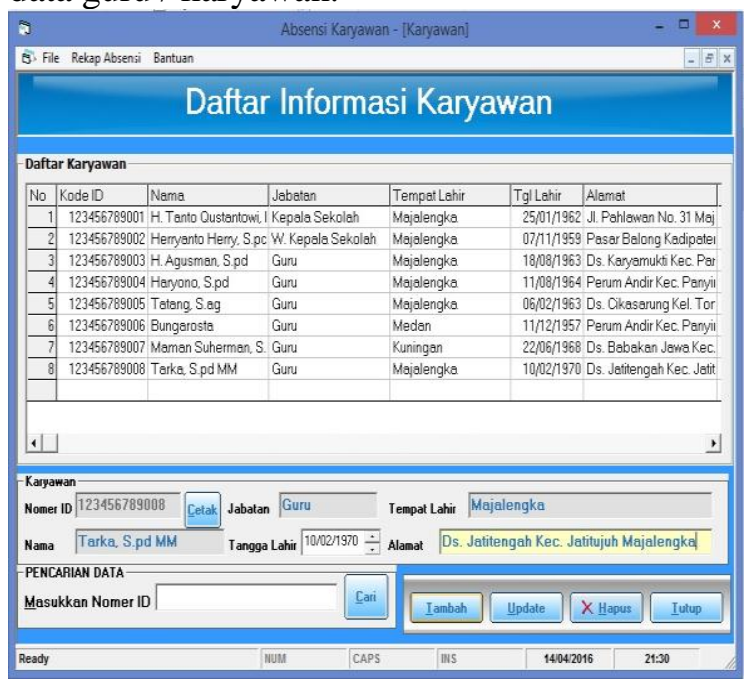

Gambar 3.15 Tampilan Data Karyawan Tambah

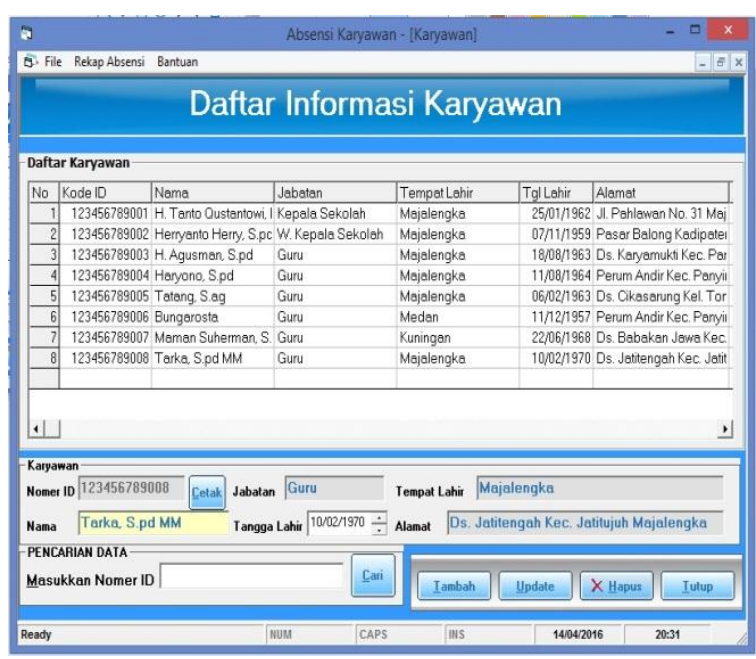

Gambar 3.16 Form Data Karyawan Edit

Computer Science | Industrial Engineering | Mechanical Engineering | Civil Engineering 


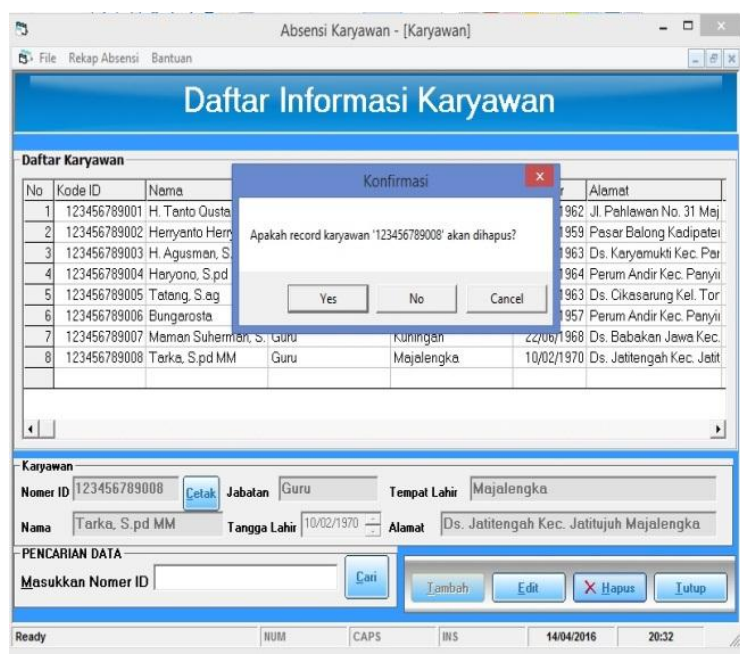

Gambar 3.17 Tampilan Data Karyawan hapus

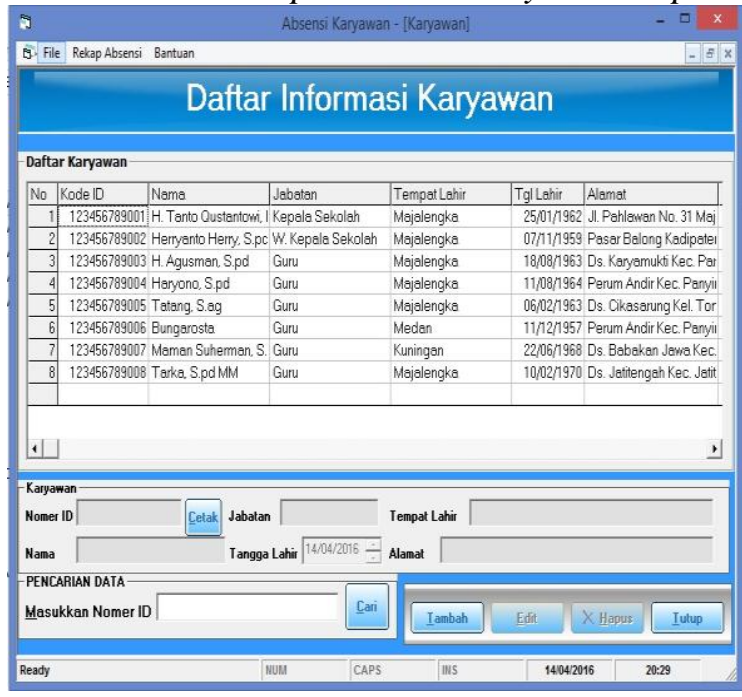

Gambar 3.18 Tampilan Data Karyawan tampil

\section{Form Data Absensi Guru / Karyawan}

Form ini menjelaskan tentang tampilan mengetahui seluruh jumlah hadir karyawan. Dan menu ini menampilkan ini guru / karyawan yang baru datang menggunakan alat scanner barcode sebagai mana fungsinya untuk guru tersebut hadir dengan 2 cara yaitu jam masuk dan jam pulang maka data akan tersimpan pada menu ini. Dan langsung tersimpan juga pada database admin. Apabila guru / karyawan sudah menyecan kode nya maka akan muncul identitasnya pada yaitu tanggal kerja nama jabatan dan statusnya masuk / pulang. Dan bisa langsung di cetak untuk arsip dirinya.

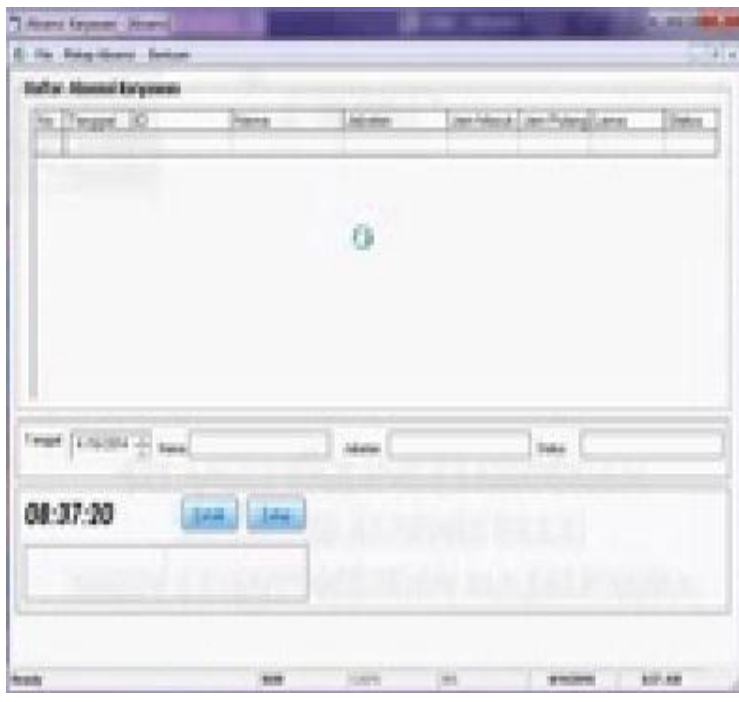

Gambar 3.19 Tampilan Data Absensi Guru / Karyawan

\section{E. Perancanagan Interface Form Rekap Laporan}

Form ini menjelaskan tentang tampilan perekapan daftar hadir untuk waktu ada perhari ada perbulan dari seluruh karyawan tersebut tujuan nya untuk di ketahui oleh kepala sekolah. Rekap laporan harian merekap di hari apa yang diinginkan asalkan periodenya sama. Kalau laporan bulanan merekapnya bulan yang diinginkan nya bulan apa asalkan periode nya tanggal awal bulan dan tanggal akhir bulan. Pada menu tampilkan akan menampilkan hasil dari rekapan tersebut bila ingin dicetak tekan tombol cetak saja.

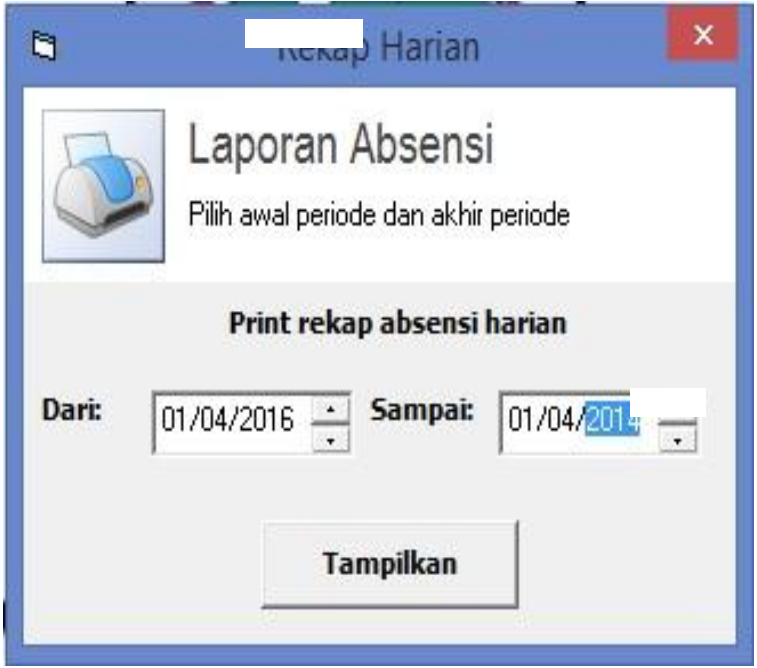

Gambar 3.20 Tampilan Rekap Laporan Harian 


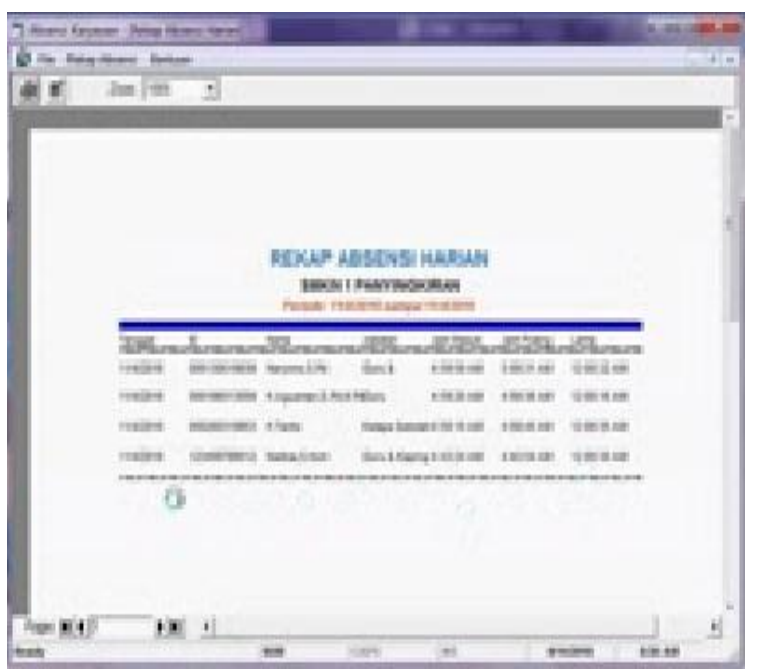

Gambar 3.21 Tampilan Rekap Hasil Laporan Harian

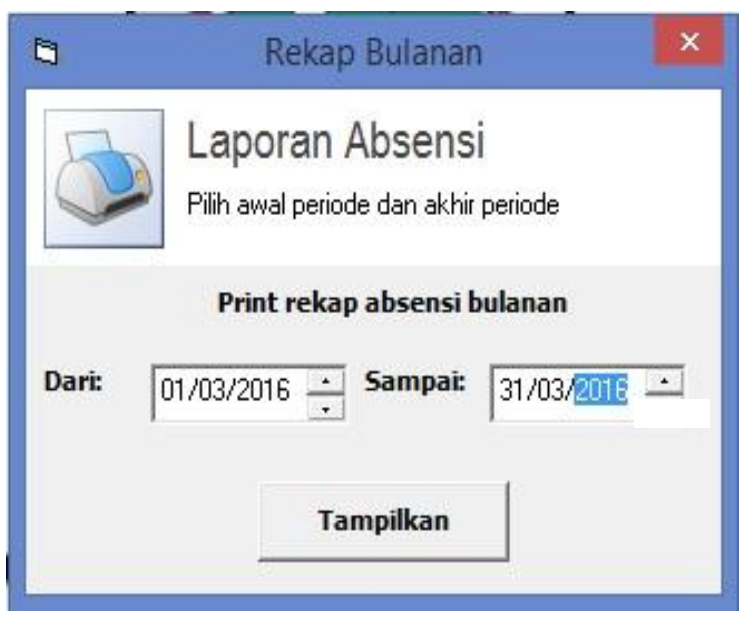

Gambar 3.22 Tampilan Rekap Laporan Bulanan

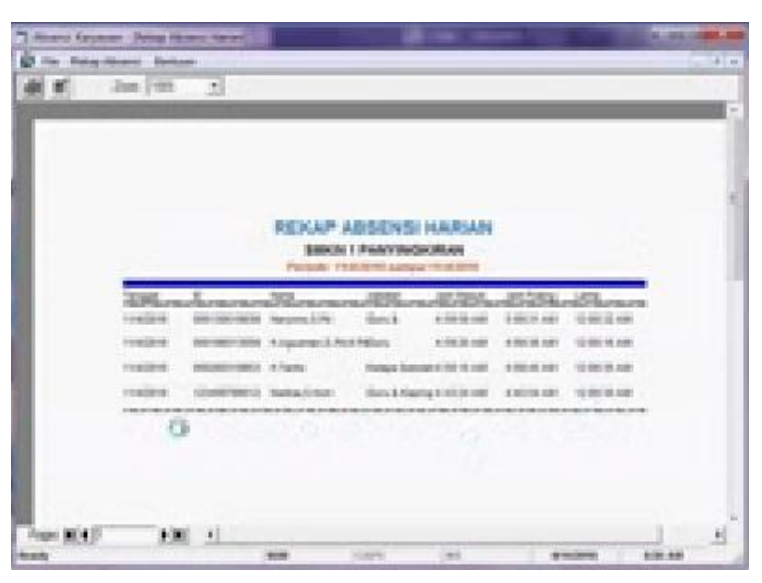

Gambar 3.23 Tampilan Rekap Hasil Bulanan

\section{F. Perancanagan Interface Form \\ Keterangan Aplikasi}

Form ini menjelaskan tentang tampilan keterangan aplikasi ini yang di dalamnya ada hak cipta pembutan aplikasi absensi guru di SMKN 1 Panyingkiran.

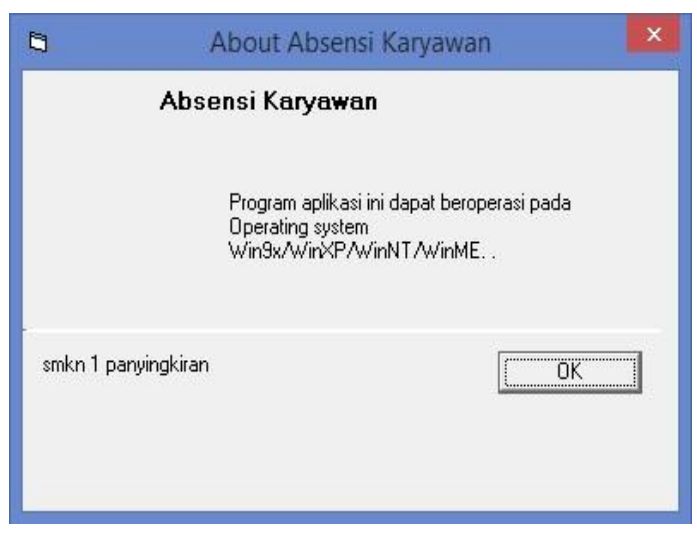

Gambar 3.24 Tampilan Keterangan Aplikasi

G. Perancangan Print Out Barcode Card di SMKN 1 Panyingkiran

Berikut ini menjelaskan tentang tampilan kartu scan barcode pada aplikasi ini yang di dalamnya ada logo sekolah, nama id, nomor id, dan batang barcodenya sendiri pada aplikasi absensi guru di SMKN 1 Panyingkiran.

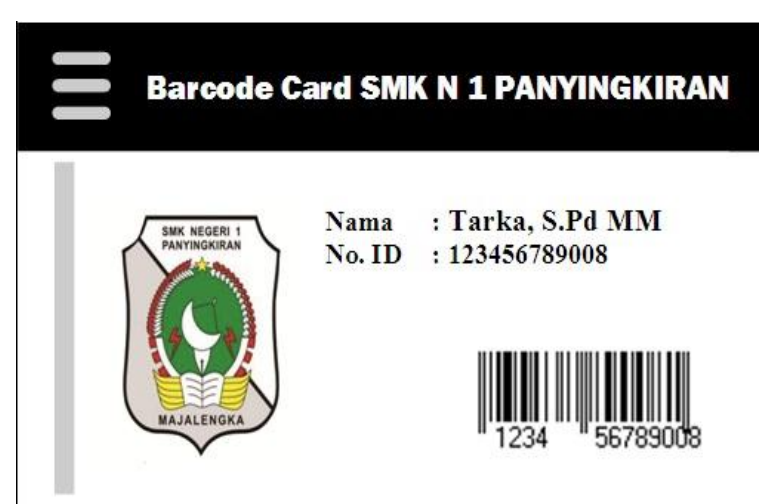

Gambar 3.25 Hasil Cetak Kartu Absensi

\section{KESIMPULAN}

\section{A. Kesimpulan}

Berdasarkan dari kajian kajian sebelumnya, maka dapat ditarik kesimpulan dsebagai berikut :

1. Aplikasi Pengolahan Data Absensi untuk Sekolah SMK Negeri 1 Panyingkiran berhasil dibangun dengan menggunakan Visual Basic dimana telah diimplementasikan daftar hadir guru (absen), untuk melihat 
kehadiran guru dengan melakukan scan barcode pada saat jam datang dan jam pulang dan melakukan pencetakan daftar hadir yang nantinya hasil tersebut bisa diberikan kepada kepala sekolah.

2. Program Aplikasi Absensi guru ini dapat mempermudah dan mempercepat waktu memperoses data absensi.

3. Dengan adanya sistem yang terkomputerisasi untuk mendorong guru untuk lebih disiplin dalam peningkatan belajar mengajar pada siswa SMKN 1 Panyingkiran.

4. Data absensi tersimpan dengan baik dan rapih bisa dilihat kapan pun dan data dapat di tambah, edit, hapus, dan di cetak harian atau bulanan.

\section{B. Saran}

Beberapa saran yang diambil dari proses analisa sampai pada pembuatan program sebagai berikut ;

1. Gunakan aplikasi ini sebagai mana mestinya dan gunakan PC yang sesuai standar pemakaian aplikasi absensi ini.

2. Guru - guru / karyawan wajib membawa kartu id barcode setiap hari.

3. Akan lebih baik jika dikembangkan kembali pada saat proses pengabsenan yang berbasis web atau adanya kemajuan teknologi secara otomatis pada aplikasi tersebut.

\section{REFERENSI}

Adi Kurniadi, Pemrograman MS. Visual Basic, PT. Elexmedia Komputindo, Jakarta, 2002

Drs. Daryanto, Belajar Komputer Visual Basic, YramaWidya, 2003

Good, 1981, kehadiran siswa di sekolah (school attandence),Carter V, New York.

H.M, Jogiyanto, 2001, Analisis dan Desain Sistem Informasi, Andi Offset, Yogyakarta.

Hayati, 2007, Konsep Dasar Teori Analisis, Lonnie D, Surabaya

J. A. Hoffer (1996)

State Transition Diagram(STD), New York

Computer Science | Industrial Engineering | Mechanical Engineering | Civil Engineering
Noertjahyana agustinus, 2008, Pengertian Lambang Folwchar Dan Metode RAD, Jakarta.

Permana, 2008, simbol-simbol flowmap, Galih S, Jakarta

Pressman, 1997, Metode Prototype Modeling, Semarang.

Saipul, 2007, Analisis Sistem, Yogyakarta

Santosa, 1995, Pengertian Pendidikan Kejuruan, Thomas H, Jakarta

Sughes Act, 1982, Memberikan Pengertian Pendidikan Kejuruan, Smith, Virginia.

Supriatno, Nono., 2004, State Transition Diagram, Jakarta

Wenrich, 1992, Menbedakan Istilah Pendidikan Kejuruan, Ralph C, Rusia 